\title{
A Church 'without stain or wrinkle': The Reception and Application of Donatist Arguments in Debates Over Priestly Purity
}

\author{
Helen Parish* \\ University of Reading
}

\begin{abstract}
This article examines the reception and application of arguments developed during the Donatist controversy in later debates over clerical celibacy, marriage and continence in the medieval and early modern church. It explores the collision of inspiration and institution in this context, arguing that the debates over sacerdotal celibacy in the medieval Latin church and Reformation controversy over clerical marriage and continence both appropriated and polemicized the history of Donatism. The way in which the spectre and lexicon of Donatism permeated the law and practice of the medieval and early modern church, particularly when it came to the discipline of clerical celibacy, is a prime example of the process of imbrication by which the history of heresy and the history of the church were constructed. As such, it exemplifies the ways in which forms of religious inspiration that manifested as dissent, such as Donatism, became embedded in the histories and self-fashioning of the institutional church.
\end{abstract}

The history and meaning of 'Donatism' in the later Western church were not the result of direct encounter with a community of believers who used such a vocabulary to describe themselves. Rather, the use of this term represented the outworking of a language that originated in the condemnation of Donatism by its opponents, and in the appropriation of that same condemnation by subsequent generations of theologians and history-writers who sought to polemicize an increasingly unfamiliar language to their own ends. This process was at work both during the period of the Gregorian reform in the Latin church and in the construction of an evangelical history of the medieval church at the hands of Reformation polemicists and martyrologists.

* Department of History, University of Reading, Whiteknights, Reading RG6 6AH. E-mail: h.l.parish@reading.ac.uk.

Studies in Church History 57 (2021), 96-119 (C) The Author(s), 2021. Published by Cambridge University Press on behalf of Ecclesiastical History Society. This is an Open Access article, distributed under the terms of the Creative Commons Attribution licence (http://creative commons.org/licenses/by/4.0/), which permits unrestricted re-use, distribution, and reproduction in any medium, provided the original work is properly cited.

doi: $10.1017 /$ stc. 2021.6 
The search for an answer to the question 'Where was your church before Luther?' was the driver behind the reimaging of the history of heresy in order to provide a location for evangelicalism within what Bruce Gordon has described as 'the expanse of Christian history'. ${ }^{1}$ The creation of a chain of 'godly witnesses' to the faith was a vital component in the construction of a history, identity and collective memory for the nascent evangelical churches, bringing the past into the present and the present into the past. ${ }^{2}$ This was a narrative of history that was distinctive in its anchor in doctrine, testimony to the long ancestry of true belief. In John Foxe's Acts and Monuments, each martyr was a link in a chain, a member of a community that existed in past and present and within which there was a commonality of belief. Those individuals who had been condemned by the church as heretics were 'the bricks and mortar with which he construct[ed] an image of the church and the lives of faithful Protestants'. ${ }^{3}$ The writing of medieval heresy was contoured by the confessionalized histories of the church produced in the same period. Representations of heresy, schism and dissent in such a schema were simultaneously more nuanced and more normative, dependent upon the exploitation of surviving sources (themselves far from objective) to enable the polemicization of the past. ${ }^{4}$

${ }^{1}$ Bruce Gordon, 'The Changing Face of Protestant History and Identity in the Sixteenth Century', in idem, ed., Protestant History and Identity in Sixteenth-Century Europe, 2 vols (Aldershot, 1996), 1: 1-22, at 3; S. J. Barnett, 'Where was your Church before Luther? Claims for the Antiquity of Protestantism Examined', ChH 68 (1999), 14-41.

2 John R. Knott, 'John Foxe and the Joy of Suffering', SCJ 27 (1996), 721-34.

3 I. Ross Bartlett, 'John Foxe as Hagiographer: The Question Revisited', SCJ 26 (1995), 772; Susan Royal, 'English Evangelical Histories on the Origins of "the Reformation", Études Épistémè 32 (2017), [online journal], at: <https://doi.org/10.4000/episteme. $1859>$, accessed 15 November 2020.

${ }^{4}$ Luke Racaut, Hatred in Print: Catholic Propaganda and Protestant Identity during the French Wars of Religion (Aldershot, 2002); Yves Krumenacker, 'The Use of History by French Protestants and its Impact on Protestant Historiography', in Bernd-Christian Otto, Susanne Rau and Jörg Rüpke, eds, History and Religion: Narrating a Religious Past (Berlin and Boston, MA, 2015), 189-202; Bertrand van Ruymbeke, 'Minority Survival: The Huguenot Paradigm in France and the Diaspora', in idem and Randy J. Sparks, eds, Memory and Identity: The Huguenots in France and the Atlantic Diaspora (Columbia, SC, 2003), 1-25; Bethany Hume, 'The Idea of Medieval Heresy in Early Modern France' (PhD dissertation, University of York, 2019); Deborah Shulevitz, 'Historiography of Heresy: The Debate over "Catharism" in Medieval Languedoc', History Compass 17/1 (2019), [online journal], at: <https://doi.org/10.1111/hic3. 12513>, accessed 15 November 2020; Antonio Sennis, ed., Cathars in Question 
In this context, it is hard to separate the early history of Donatism, or indeed any heresy, from the inescapable tendency of doctrinal deviance to become first a label and then a pejorative slur. Ali Bonner's recent analysis of the history of Pelagianism treats that heresy as a construct of Augustine rather than Pelagius; the same process is also seen at work in the construction of Arianism and Gnosticism..$^{5}$ Any history of Donatism and its legacy is similarly non-linear and untidy, but despite (or perhaps because of) that, it provides an illuminating illustration of the ways in which a rhetoric of dissent, opposition and separatism could become embedded in the structures of the visible, institutional church. The existence or otherwise of a fundamental connection between doctrinal and sacramental purity was a critical component in the solidification of the Donatist schism. In the eyes of the Donatists, those bishops and clergy who during periods of imperial persecution had renounced their faith and handed over the Scriptures to the authorities (and were therefore criticized by the Donatists as traditores) had been rendered impure by their actions; to allow such impurity to intermingle with the purity of the Donatist sect was to tolerate sin, and the presence of sin in the sacraments that lay at the very heart of the true church. If the ordination of clergy by the traditor bishops was invalid, then their errors also permeated the sacraments of baptism and the eucharist, casting doubt upon their validity and efficacy. In the Donatist schism (and the responses to it) we can see elements of what was to become an enduring debate about the relationship between the sacraments and the personal moral and spiritual standing of the celebrant, a debate that was eventually to crystallize around the assertion that the validity

(Woodbridge, 2016); R. I. Moore, The War on Heresy: Faith and Power in Medieval Europe (London, 2012).

5 John Arnold, Inquisition and Power: Catharism and the Confessing Subject in Medieval Languedoc (Philadelphia, PA, 2001); Caterina Bruschi, "Magna diligentia est habenda per inquisitorem": Precautions before Reading Doat 21-26', in eadem and Peter Biller, eds, Texts and the Repression of Medieval Heresy (Woodbridge, 2003), 81-110; Shulevitz, 'Historiography'; Monique Zerner, Inventer l'hérésie? Discours polémiques et pouvoirs avant l'Inquisition (Turnhout, 1998); Ali Bonner, The Myth of Pelagianism (Oxford, 2018); David M. Gwynn, 'From Iconoclasm to Arianism: The Construction of Christian Tradition in the Iconoclast Controversy', Greek, Roman and Byzantine Studies 47 (2007), 225-51; idem, The Eusebians: The Polemic of Athanasius of Alexandria and the Construction of the 'Arian Controversy' (Oxford, 2006), 169-244, 'The "Arianism" of the "Eusebians". 
of the sacraments was not anchored in the conduct and conscience of the priest, but existed rather ex opere operato, by virtue of the work carried out. ${ }^{6}$ The debates unleashed both within Donatism and between Donatists and their critics were woven into the fabric of the medieval Catholic Church, providing a language of priestly purity and pollution that remained with the church in the centuries that followed. ${ }^{7}$

But if the debate was enduring, its origins remained opaque. References to Donatism in medieval and Reformation sources demonstrate the extent to which the term 'Donatist' could be imbued with a meaning that was far from specific. The Donatism that existed within the pages of medieval and early modern controversy was far broader than that which had been described by St Augustine, indicating that the term had become a polemical shorthand for a set of beliefs that were far from consistent. The heresy was known and recognized, but rarely encountered first-hand, by those who exploited its multiple messages. Was it the case that Donatism influenced later debates over priestly purity because the Donatist controversy was still, centuries later, common theological currency? Or (perhaps more likely) did subsequent generations devise their own definition of Donatism in order to press a familiar name into service in order to condemn their opponents, as, for example, in the debates over clerical marriage in the mid-sixteenth century? The history of Donatism was repeatedly (re)written and (re)applied by those who had had no direct contact with the movement, and that seemingly flawed and fluid history is a rich example of the manipulation of the narratives of the past in the service of the needs of the present.

6 Jesse Hoover, 'They bee Full Donatists', Reformation \& Renaissance Review 15 (2013), 154-76.

7 For fuller discussion of the early history of Donatism, and particularly its construction at the hands of St Augustine, see Paul Keresztes, Imperial Rome and the Christians: From the Severi to Constantine the Great, 2 vols (Lanham, MD, 1989), 2: 67-83; Eusebius of Caesarea, The Ecclesiastical History, trans. Kirsopp Lake, 2 vols, Loeb Classical Library (London, 1926), 447-61; W. H. C. Frend, The Early Church (London, 1965), 116; Brent D. Shaw, Sacred Violence: African Christians and Sectarian Hatred in the Age of Augustine (Cambridge, 2011); Maureen A. Tilley, trans., Donatist Martyr Stories: The Church in Conflict in Roman North Africa (Liverpool, 1997); eadem, 'Dilatory Donatists or Procrastinating Catholics: The Trial at the Conference of Carthage', $\mathrm{ChH}$ 60 (1991), 7-19; eadem, 'Sustaining Donatist Self-Identity: From the Church of the Martyrs to the Collecta of the Desert', JECS 5 (1997), 21-35; eadem, 'Redefining Donatism: Moving Forward', Augustinian Studies 42 (2011), 21-32; Richard Miles, ed., The Donatist Schism: Controversy and Contexts (Liverpool, 2016). 
It is in the debate over the connection between the purity of the priesthood and the efficacy of the sacraments that the shadow of Donatism and other such heresies, real or imagined, in the later medieval church is most visible. As Henry C. Lea observed in his (albeit rather polemical) history of clerical celibacy, 'the hateful name of Manichaean acquired a sinister notoriety which maintained its significance for a thousand years' ${ }^{8}$ Like Donatism, Manicheanism exerted a substantial influence over the growth of asceticism and the rhetoric of priestly purity in the institutional church. Similar connections between the repression of dissent in the early church and the subsequent construction of histories of heresy have been raised more recently in Ali Bonner's discussion of what she describes as the 'myth' of Pelagianism. Simply put, Bonner argues, Pelagius was not Pelagian; the moral and theological tenets attributed to Pelagianism were acquired rather later in its history, and as part of a conscious desire to invent heresy in order to define and relocate orthodoxy. ${ }^{9}$ We can observe the same evolutionary trajectory in the punctual and systemic presence of Donatism within the dialogues of the medieval and early modern churches. Whether or not Donatism existed with a historical reality, the 'intuitive practicality' of even the most inconsistent narratives of heresy rendered them real in the language of doctrinal debate. Bonner's contention that the term 'Pelagian' should be abandoned altogether 'because it introduces a faulty paradigm into every sentence in which it is used' is certainly compelling, and applies not only to Pelagianism but also to Donatism. ${ }^{10}$ But even if the model of the nature and impact of heresy is erroneous, there is still much that we can learn from the perpetual and polemical (re)construction of that error.

The way in which the spectre and lexicon of Donatism permeated the law and practice of the medieval church, particularly when it came to the discipline of clerical celibacy, is a prime example of the process of imbrication by which the history of heresy was constructed. Debates over the purity of the priesthood were embedded in the reforming culture of the eleventh-century church. In the mideleventh century, the Patarines of Milan launched a violent campaign

\footnotetext{
8 Henry C. Lea, History of Sacerdotal Celibacy in the Christian Church, 2 vols (London, 1904), 1: 33.

9 Bonner, Pelagianism, 26-8.

${ }^{10}$ Ibid. 305.
} 
to expel simoniacal and married priests from the church, a campaign that culminated in the deposition of the bishop of Milan on grounds of simony. The Patarines, as Janine Larmon Peterson has observed, argued that only the virtuous and morally pure had the right to judge other Christians, a belief that resonated with early Donatist ideas that the catholic church had condemned, but which had not entirely disappeared. The label Patarine, like Donatist, came to designate a loosely defined form of heresy, although its arguments became largely ineffectual in the face of inquisitorial process. As Lucy Bosworth has demonstrated, catalogues of heresies that had their roots in the early church were a mainstay of medieval writing on the history of heresy, and encouraged a tendency to see the roots of all heresy in the nascent Christian church. ${ }^{11}$ The actions of the Patarines did not have papal sanction, but the language that they used to denounce clerical simony and unchastity certainly chimed with the voices and vocabulary of the ecclesiastical reformers of the eleventh century. Cardinal Humbert's Three Books against the Simoniacs called on princes and laymen to address the damage that the sale of offices had caused to the church, and encouraged the faithful to absent themselves from masses celebrated by simoniac priests. In the first instance, the debate over sacramental obligation was confined to its connection with simony, but by the end of the century the focus had shifted to the sacraments of the 'schismatics' who had backed the emperor and the antipope against Gregory VII. ${ }^{12}$ Here, in the views of the imperialist party expressed by Wibert of Ravenna, we see language akin to Augustine's defence of the validity of the sacraments of the traditor clergy against the objection of the Donatists. Denouncing the views of Hildebrand (Gregory VII), Wibert complained that it was the pope who was schismatic, precisely because he 'taught that the sacraments of unworthy and excommunicate priests were polluted ... [and] commanded that they were not to be received and indeed forbade them to be called sacraments'. ${ }^{13}$

\footnotetext{
11 Janine Larmon Peterson, Suspect Saints and Holy Heretics: Disputed Sanctity and Communal Identity in Late Medieval Italy (Ithaca, NY, 2019), 155-6; Lucy Bosworth, 'Perceptions of the Origins and Causes of Heresy in Medieval Heresiology' (PhD thesis, University of Edinburgh, 1995).

12 I. S. Robinson, 'Reform and the Church, 1073-1122', in David Luscombe and Jonathan Riley-Smith, eds, New Cambridge Medieval History, 4: c.1024-c.1198, Part 1 (Cambridge, 2004), 268-334, at 307-10.

13 On the Schism of Hildebrand, quoted in Robinson, 'Reform', 310.
} 
The link with Donatism here was far from fully formed, but the exchanges provide evidence of the appropriation of earlier heresies, and the condemnation of such beliefs, to prove the error inherent in the opposing view.

Gregory was swift to reject such allegations, but we can hear echoes of that same connection between moral error and sacramental participation in demands that priests, deacons and subdeacons who were guilty of the 'sin of fornication' should not be permitted to enter churches without first doing penance, and the accompanying instruction that the laity were to withdraw from the sacraments of such priests, 'because their blessing is turned into a curse and their prayer into a sin'. The language of this debate was resonant with references to the heresies of the early church. Humbert referred to married priests as 'Nicolaitans', a sect characterized by moral depravity (Revelation 2), ${ }^{14}$ while Peter Damian described both clerical marriage and incontinence as fornication and a 'foul commerce', asserting that 'they are rightly called Nicolates when they defend their deathbringing plague as though by authority'. The genealogy of the debate over clerical marriage was not yet fully formed, but the desire to locate the controversy firmly within the history of the early church is evident. ${ }^{15}$

This connection between theological corruption and carnal concupiscence was neither novel nor unique to the debate over clerical marriage; such language punctuated the denunciations of other medieval heresies, including Waldensianism, the Cathars, the Beguines and even the Publicani. ${ }^{16}$ Indeed the proliferation of such judgements contributes to the challenge of identifying the precise origins of such ideas. And as recent historians of medieval heresies have reminded us, the force and impact of such accusations was not simply to justify the persecution of morally depraved heretics, but also to define and enforce a normative pattern of belief and behaviour within Western Christendom and orthodox Christian society. The consequence - and perhaps even the intention - was the compilation of a profile of dissent that, once defined, served either to define orthodoxy and protect it from the pollution of doctrinal and moral error or

14 C. N. L. Brooke, Medieval Church and Society (London, 1971), 72-3.

15 H. E. J. Cowdrey, Pope Gregory VII, 1073-1085 (Oxford, 1998), 283.

16 Walter Wakefield and Austin Evans, Heresies of the High Middle Ages (Columbia, SC, 1969), 220, 101. 
to create a fear of such pollution that then became a means of imposing order and defending the boundaries of Christian orthodoxy. ${ }^{17}$

How high was the step from the instructions in conciliar legislation to depose simoniacs and withdraw from the sacraments of married or unchaste priests to a more iconoclastic assertion that those clergy who were tainted with the sins of simony and fornication were capable of spreading that pollution via their sacramental celebration? The articulation of connections between clerical unchastity and the efficacy or value of the eucharistic celebration deployed a language that was common to the leaders of reform and to other forms of devotional and pastoral writing, as well as the literature of complaint. ${ }^{18}$ Humbert's denunciation of the married clergy of the Eastern Church is a case in point: these priests, he argued, were so 'completely enervated and exhausted by the recent pleasures of the flesh and thinking in the midst of the holy sacrifice about how to pleasure their wives, they handle the immaculate body of Christ and distribute it to the people. Immediately afterward they turn their sanctified hands to touch the limbs of women.' 19 The horrifying image of the priest whose hands touched both the body of Christ and the body of a whore was exploited to the full by Peter Damian in his assertion that bodily purity was a necessary part of priestly function. ${ }^{20}$ However, even Peter Damian stopped short of asserting that the validity or efficacy of the sacrament was connected to the moral standing of the celebrant. ${ }^{21}$ Nonetheless, as Louis Hamilton has argued, the debates over simony and nicolaitism in the eleventh century did not result in a triumph for the Augustinian view. The controversy placed Donatism at the centre of the debate, and the outcome was in fact a practical triumph for the 'Donatist' position. Damian was a

\footnotetext{
17 Robert I. Moore, The Formation of a Persecuting Society: Power and Deviance in Western Europe, 950-1250 (Oxford, 1987); Mary Douglas, Purity and Danger: An Analysis of the Concept of Pollution and Taboo (London, 2002).

18 Phyllis G. Jestice, 'Why Celibacy? Odo of Cluny and the Development of a new Sexual Morality', in Michael Frassetto, ed, Medieval Purity and Piety: Essays on Medieval Celibacy and Religious Reform (New York, 1998), 81-115.

19 Humbert of Romans, Contra Nicetam (PG 143, 1000), quoted in Amy Remensnyder, 'Pollution, Purity and Peace: An Aspect of Social Reform between the Late Tenth Century and 1076', in Thomas Head and Richard Landes, eds, The Peace of God: Social Violence and the Religious Response in France around the Year 1000 (Ithaca, NY, 1992), 280-307, at 301.

20 Remensnyder, 'Pollution, Purity and Peace', 301.

${ }^{21}$ R. I. Moore, The Origins of European Dissent (Oxford, 1985), 60-1.
} 
perceptive reader of Augustine, but still capable of confusing the issue of sacramental efficacy by fluctuating between the assertion of a link between the validity of the sacrament and priestly purity and the denial that such a link existed. In the Patarine affair, moderation triumphed, but after Damian's death the Donatist position reemerged, particularly in debates over the dedication of churches. ${ }^{22}$

In general it was agreed that incontinent priests committed sacrilege, but did not diminish the sacrament. ${ }^{23}$ In 1382, the Blackfriars Council condemned explicitly the proposition that 'a bishop or priest in mortal sin does not ordain, consecrate or baptize', derived from the writings of John Wycliffe. ${ }^{24}$ The propositions that were condemned at that council informed the more general condemnation of Wycliffe's theology at the Council of Constance in 1415 as part of its proceedings against Jan Hus. The condemnation at Constance did not reflect the entirety, or the nuances, of Wycliffe's thinking on the connection between the morality of the priest and the ministration of the sacraments, but by using this particular phrasing, the council clearly recognized the potency of the language and its implications. $^{25}$ The demand that priests should forsake the corruption of worldly concerns in order to focus on the spiritual concerns of the lex Christi was not tied to the efficacy of the eucharist alone; Wycliffe's commentary on the 'mortal sin' of bishops and priests extended into a broader denunciation of the nature and impact of corruption as a disease that infected the church, and which should excised in the same way as a surgeon would remove a tumour. Such language, in the eyes of his critics, echoed the assertions that had been condemned in Donatism. ${ }^{26}$ Wycliffe adopted a more conciliatory tone in De Ecclesia and the Sermones, in which he argued that priests in a state of mortal sin might indeed minister to the faithful, but 'damnably'. The Decretum was invoked by Wycliffe to defend the proposition that

\footnotetext{
22 Louis Hamilton, 'Sexual Purity, "the Faithful” and Religious Reform in Eleventh Century Italy: Donatism Revisited', in John Doody, Kevin Hughes and Kim Paffenroth, eds, Augustine and Pollution (Oxford, 2005), 237-60.

23 Helen Parish, Clerical Marriage and the English Reformation: Precedent, Policy and Practice (Aldershot, 2000), 167-8.

24 Peter Marshall, The Catholic Priesthood and the English Reformation (Oxford, 1994), 48.

25 Walter W. Shirley, ed., Fasciculi Zizaniorum magistri Johannis Wyclif cum tritico, RS 5 (London, 1858), 277-82.

26 Ian Levy, 'Was John Wyclifs Theology of the Eucharist Donatistic?', Scottish Journal of Theology 53 (2000), 137-53.
} 
God's grace could be conferred through 'both good and evil ministers, without imperilling the faithful'. ${ }^{27}$ However, his continued and vehement criticism of clerical immorality did not establish a clear distance between Wycliffe's understanding of the connection between priestly morality and sacramental efficacy, and that of the Donatist heresy, or at least the historical construction of that heresy. In England, the persecution of Lollard heresies exposed the extent to which anxieties about the connection between clerical morality and sacramental efficacy had come to punctuate the rhetoric of anticlericalism and anti-sacerdotalism. In 1426, the Franciscan Thomas Richmond was required to retract the opinion that 'a priest in mortal sin does not consecrate the body of Christ'. ${ }^{28}$ This assertion certainly featured prominently in the Lollard heresy trials. Even considering the extent to which such comments were elicited by specific questioning that imposed the concerns of the institutional church upon a more disparate set of beliefs, sacramental efficacy was not only a matter for the theologians. That much was recognized in the vernacular polemic of the early sixteenth century. Thomas More, in the Dialogue Concerning Heresies, launched a spirited attack on the assertion that the sacramental ministry of a priest in sin might be ineffective. 'That sacred sacrifice and sweet oblation of Christ's holy body offered up by his office, can take none impairing by the filth of his sin,' More argued against the Messenger, 'and is to God as acceptable and to us as available for the thing itself, as though it were offered by a better man.'29 That such a discussion took place within the structure of the Dialogue is perhaps indicative of the extent to which the opinion articulated by the Messenger was assumed to reflect a more widely held belief.

Such imagery and narratives used the same language as had been used by the Donatists, but, it is important to note, without the same intent to assert that the sacraments of immoral clergy were tainted and rendered invalid. However, the issue could be emotive. Priestly incontinence, it was suggested, was not just morally indefensible, but capable of ripping apart or even crucifying the body of Christ, who

\footnotetext{
27 John Wycliffe, De Ecclesia 19; De Antichristo 48. For a fuller discussion, see Anthony Kenny, Wyclif (Oxford, 1985), 71-3.

28 '[S]acerdos in peccato mortali lapsus, non est sacerdos': D. Wilkins, Concilia Magnae Britanniae et Hiberniae, 2 vols (London, 1737), 2: 488.

29 Thomas More, A Dialogue concerning Heresies, ed. Thomas M. C. Lawler, Germain Marc'hadour and Richard C. Marius, CWTM 6 (New Haven, CT, 1981), 299.
} 
appeared with torn clothes or bleeding wounds in the visions of unchaste clerics who had chosen to celebrate mass. ${ }^{30}$ As the cult of the eucharist became embedded in popular devotional practice, a genre of miracula in which Christ appeared physically on the altar could readily accommodate eucharistic miracle stories in which the transformation of the bread and wine became a trope for assessing the moral purity, or otherwise, of the priest. Unworthy priests who celebrated mass were reminded of their obligation to lead a pure and chaste life by a consecrated host that turned to coal in their mouth, or by the appearance of a human finger that removed the host from the unclean hands of the priest at the moment of consecration. ${ }^{31}$

In particular, eucharistic visions experienced by female saints at the elevation became, in Caroline Walker Bynum's phrase, 'a kind of litmus test for clerical immortality or negligence', from which the inescapable (if still theologically controversial) conclusion was that any unusual occurrences could be attributed to the incontinence of the priest who approached the altar with unclean hands. ${ }^{32}$ A eucharistic miracle recorded in the Cistercian Exordium Magnum described the experience of a monk present at a mass celebrated by an 'unchaste and dissolute' priest: the monk observed that whenever the priest turned to face the congregation, a holy child would appear upon the altar, and then rush to hide behind the chalice 'as if avoiding the priest's unclean breath' when the celebrant turned to the altar. ${ }^{33}$ Miracula of this type were not reserved for the clergy alone. Lay men and women who received the eucharist while in a state of sin were reported to have choked, witnessed the host fly out of their mouths, experienced demonic torture or observed the host bleed. ${ }^{34}$ How much more telling were these miracles if they involved priests?

There is a question to ask here about the extent to which the theoretical distinction between defects in the chastity of the priesthood and defects in sacramental ministry was recognized and understood

30 Remensnyder, 'Pollution', 297 n. 65.

31 Miri Rubin, Corpus Christi: The Eucharist in Late Medieval Culture (Cambridge, 1991), 125.

32 Caroline Walker Bynum, Holy Feast and Holy Fast: The Religious Significance of Food to Medieval Women (Berkeley, CA, 1987).

33 Stephen Justice, 'Eucharistic Miracle and Eucharistic Doubt', Journal of Medieval and Early Modern Studies 42 (2012), 307-32.

34 Rubin, Corpus Christi, 125-6. 
by the laity, particularly given instructions such as those issued at the Lateran Councils of the early twelfth century that the faithful should absent themselves from the masses of unchaste and simoniac priests. To do so on the basis that such sacraments were invalid looked very much like latent Donatism, but if that was not the intention, how widely was this understood? 35 Conciliar decrees and miracles of moral judgement may well have underpinned the kind of language that Peter Marshall observed in lay demands that a priest who prayed for their soul should be an 'honest man', a shorthand for an insistence on clerical continence. ${ }^{36}$ Such anxiety and language was itself tied inextricably to the vocabulary that defined the priesthood in the late medieval church. As Marshall notes, the priest, and the priest alone, was permitted to 'touch the body of Christ Jesus', and that distinction both described and imposed the separation of the priest from the laity. ${ }^{37}$

Dionysius the Carthusian's summary of the qualities demanded of the clergy was informed by this assertion that priests alone enjoyed such proximity to the most sacred. If purity was expected of all who would devote themselves to the service of God, how much more vital was it, Dionysius argued, to recognize that the true servants of Christ were those who 'ponyshed theyr fleshe' with abstinence from vice and concupiscence. ${ }^{38}$ Priests, whose duty and vocation was to serve God with a pure heart and a chaste body, committed a grievous sin by conceding to the temptations of the flesh, 'for in the synne of the fleshe is the moste great $\&$ manifest turpitude bestlynes / dishonestie / and fylthynes', all of which distracted and detracted from the holy. ${ }^{39}$ 'Wanton prestes' who continued in such living presented a poor example to the laity, but more importantly failed in their obligations towards that which was most sacred:

In so much as that that holy ministerye of the altare is most pure / and the sacramentes of the churche be most clene and ghostly (especially the sacrament of the blessyd body of our lord) it is most vicyous and

\footnotetext{
35 Malcolm Lambert, Medieval Heresy: Popular Movements from Bogomil to Hus (New York, 1977), 37.

36 Marshall, Catholic Priesthood, 51-3, 161-2.

37 Ibid. 44.

38 Dionysius Carthusianus, The lyfe of Prestes (London, 1533), sigs B5r-v.

39 Ibid., sigs $\mathrm{C} 4 \mathrm{v}-5 \mathrm{r}$.
} 
inconuenie[n]t that the minystres of the church and altare / should so precyous sacramentes defyle and corrupt. ${ }^{40}$

Dionysius invoked the authority of Levitical law to argue that the injunction 'be ye holy for I am holy' was a necessary instruction to the Catholic priesthood. In the sacrifice of the mass, priests encountered an obligation to 'be ware of all unlawful actes / that we may lyft by clene handes unto almyghty god (which sayth) be you holy for I am holy'. ${ }^{41}$ The same passage was exploited by Thomas Martin in his denunciation of clerical marriage in England in the middle of the sixteenth century. Priests, he argued, were subject to the same demands as those imposed in Levitical law. ${ }^{42}$ If the priests of the Old Testament abstained from their wives, the priests of the new law were under an even greater obligation to chastity, not least because while the law of Moses referred to the sacrifice of animals, the discipline of the church referred to the sacrifice of the mass and therefore Christ himself. In these circumstances, Thomas Martin argued it was only right that 'Christian priestes which muste offer a more worthy, a more noble, a more divine sacrifice, then all the priestes of the olde lawe shoulde liue in perpetual chastitye'. ${ }^{43}$

Such language did not contradict the insistence that the validity of the sacraments was not impaired by the imperfections of the clergy, but it is clear that condemnations of the failure of the clergy to keep to their obligation to celibacy was frequently couched in terms of the dishonour which it caused to the sacrament, and to God. Priests who were guilty of breaching their vows were accused of committing sacrilege, as the author of The Lyfe of Prestes explained: 'It is callyd sacrylege / for that it corruptyth holy ordre / by unworthy handelynge and myscheuous abusyng that thyng that to god is consecrate'. ${ }^{44}$ The bodies of priests should have been the temples of God, but had become instead the temples of the devil. ${ }^{45}$ Such charges of

${ }^{40}$ Ibid., sigs C8r-v, G4v, C5r.

41 Ibid., sig. F8r.

42 Thomas Martin, A Traictise declaring and plainly prouyng that the pretensed marriage of priestes, and professed persones, is no marriage but altogether unlawful (London, 1554), sigs Ll4v, Mm1r.

43 Ibid., sig. B4v, cf. Bb2v.

44 Dionysius, Lyfe of Prestes, sigs D1r, G2v.

45 Ibid., sig. H2r; a similar argument is made at sig. G7r using St Bernard's condemnation of a priest who should have been the 'sepulture of the blessyd body of Chryst', but had fallen from purity. 
profanation were repeated elsewhere. In Dives and Pauper, the character of Pauper explained that while there were many different degrees of lechery, clerical immorality was the one most worthy of particular opprobrium on the grounds that those who broke their chastity were guilty not only of adultery, but also of sacrilege and treachery. ${ }^{46}$ The fact that Christ was still present in the elements consecrated by such priests did not lessen the serious nature of their transgression; indeed the sin was worsened by the fact that Christ was present and thus dishonoured.

As we have seen, potent intersections existed between such rhetoric, a burgeoning lay eucharistic piety and the visibility of narratives of unchaste clergy who presumed to handle the sacraments. The image of the concubinary priest who touched the consecrated elements with 'unclean' hands was a common theme not only in medieval Catholic, but also in later, evangelical, literature. Thomas Brunton, the bishop of Rochester, commended a priest who had refused to celebrate mass because he had slept with a concubine the previous night. The immoral conduct of the priest was not in question, but his decision to avoid handling the eucharistic elements while in a state of sin presented a pious but perhaps pastorally challenging message, given that the 'unclean' hands of the celebrant should not affect the sacrament itself. In pre-Reformation literature, the object of derision was the concubinary priest, but the image was later applied by Catholic polemicists to contact between married priests and their wives. Thomas Martin protested that the sacraments were treated with disdain in England, and had few doubts as to why this had situation had arisen. 'The cause of the which contempt', he argued, 'issued forth partly of the unreuerent and vncleane handling of the holy sacramentes by the old priestes, partlye also, \& that most especially by the unlawful and most wicked marriages of the new ministers. ${ }^{47}$ The dishonour done to the sacraments by impure priests was matched, if not exceeded, by that inflicted by married clergy. But whether such concern about the 'honesty' or continence of a priest was genuinely indicative of a spirit of lay Donatism is a more complex question. In the centuries after its effective suppression, Donatism had become a convenient shorthand, or term of abuse, that was not always deeply rooted in the clash between Augustine and those

46 Anon., Dives and Pauper (London, 1534), fol. 226r.

47 Martin, Pretensed Marriage, sig. A4v. 
that he defined as Donatists. The meaning of the heresy had become more broadly applicable, tied to concerns about clerical immorality, rather than to the specific challenges posed by Donatus and his followers to the structures of the church.

In their defence of the validity of the sacraments of incontinent priests, neither the councils of the church nor Catholic polemicists and pastoral writers proposed that clerical misconduct and immorality should be condoned, or that it was inconsequential. It was possible for a Corpus Christi sermon to assert that the character of the priest had no influence upon the efficacy of the sacraments, while at the same time reminding priests that they had received a gift from God 'pat he gaf neuer to no angele in Heuen: pat is forto make Godis body. ${ }^{48}$ The Council of Toledo (1302) had instructed that concubinary priests were to be deprived of the fruits of their benefices and suspended from office. In England, the Winchester Synod of 1308 took similar action against incontinent priests, and that same concern and language can be seen in the decrees of councils in Ravenna (1314), Toledo (1324), Florence (1346), Prague (1355) and Magdeburg (1370). By this point, any distinction between clerical marriage and clerical incontinence had been eroded; the language used was that of concubine, focaria, solute or pedisseca, suggesting that the focus of the problem had shifted to priestly immorality rather than illicit marriage per se. ${ }^{49}$ The Franciscan preacher William Staunton denounced the behaviour of unchaste priests who had 'become most fowl in the Devil's service'. ${ }^{50}$ John Colet condemned the 'abhominable impiety' of the multitude of the clergy, 'who fear not to rush from the bosom of some foul harlot into the temple of the church, to the altar of Christ, to the mysteries of God'. ${ }^{51}$ Thomas More defended

\footnotetext{
48 Mirk's Festial: A Collection of Homilies by Johannes Mirkus, ed. T. Erbe, EETS extra series 96 (London, 1905), 169.

49 Jennifer Thibodeaux, 'Man of the Church or Man of the Village? Gender and Parish Clergy in Medieval Normandy', Gender and History 18 (2006), 380-99, at 388; J. Gaudemet, 'Le Celibat Ecclesiastique. Le Droit et la practique du XI ${ }^{\mathrm{e}}$ au XII ${ }^{\mathrm{e}}$ siècle', Zeitschrift der Savigny-Stiftung fur Rechtsgeschichte, Kanonistische Abteilung 68 (1982), 1-31, especially 4-5; B. Schimmelpfennig, 'Ex Fornicatione Nati: Studies on the Position of Priests' Sons from the Twelfth to the Fourteenth Century', Studies in Medieval and Renaissance History n.s. 2 (1980), 3-50, at 33-6.

50 G. R. Owst, Literature and Pulpit in Mediaeval England: A Neglected Chapter in the History of English Letters \& of the English People (Oxford, 1961), 247, 267.

51 Dionysius, Lyfe of Prestes, sig. G7v; Christopher St German, The Debellation of Salem and Bizance, ed John Guy et al. (New Haven, CT, 1987), 379; Marshall, Catholic Priesthood, 46.
} 
the efficacy of the sacraments of unchaste priest, but that defence was accompanied by the blunt judgement that although such sacraments were still channels of God's grace, 'yet he is with that priest's presumption highly discontented', because in such circumstances 'Christ is also betrayed into the hands of sinners'. ${ }^{52}$ Priests who celebrated mass and handled the consecrated elements with unclean hands were, in a broad consensus, acting in a way that invited criticism that was of necessity more simplistic than any response. Into that gap between the outward character of the priest and their sacerdotal function, satire might readily intrude. Desiderius Erasmus, for example, complained that it was all too easy for a priest to adjourn to parties, gambling, hunting, idleness and other refuges of mankind only moments after standing at an altar at which 'angels wait upon' him. ${ }^{53}$ The language of Erasmus was far from impotent, but was certainly more measured than that of some polemicists.

The malleability of the language that connected the theology of the eucharist with the moral standing of the priest was exploited ruthlessly by evangelical polemicists in the middle decades of the sixteenth century. Evangelical polemicists repeatedly invoked the idea that theological and moral corruption were coterminous, but it was in the discussion of the eucharist that the link was most clearly defined, precisely because the requirement to celibacy for the priesthood was so inextricably tied to the theology of the mass. In the (admittedly not entirely objective) eyes of John Bale, the theology of transubstantiation was itself fundamentally flawed by its association with Peter Lombard, a child of a nun, a suggestion that has the ring of fiction rather than fact. ${ }^{54}$ Anthony Gilby asserted that transubstantiation was prima facie an erroneous doctrine because immoral priests could not be agents of the miraculous. God, Gilby argued, although omnipotent, 'wyll not be chaunged into any newe formes, by the mu m]bling and breathing of an whoremo[n]ger or sodomiticall priest'. ${ }^{55}$ John Ramsey demanded that his Catholic opponents justify

\footnotetext{
52 More, Dialogue, 299; More, De Tristitia Christi, 1: The Valencia Manuscript: Facsimiles, Transcription, and Translation, ed. Clarence H. Miller, CWTM 14/1 (New Haven, CT, 1976), 351.

53 Marshall, Catholic Priesthood, 46 n. 70.

54 John Bale, A Mysterye of Iniquyte Contayned within the Heretycall Genealogy of Ponce Pantolabus (Antwerp, 1545), fol. 33v.

55 Anthony Gilby, An Ansvver to the Deuillish Detection of Stephane Gardiner (London, 1547), sigs 56v-57r.
} 
their claims that 'horemasters prestes, by their ministracio[n] so com / to alure Christ out of heaue[n] as me[n] do byrdes to twigges'. ${ }^{56}$ Such views were common in the flurry of anti-mass tracts printed in England early in the reign of Edward VI. The anonymous author of The $v$. abhominable Blasphemies conteined in the Masse argued that blasphemy was embedded in any assertion that the mass was a true sacrifice and oblation by which the priest and the participants could obtain forgiveness for their sin ex opere operato, because such a claim denied the merits of the sacrifice of Christ. Anti-sacerdotalism fuelled an argument that the nature of the Roman Catholic priesthood detracted from the eternal priesthood of Christ, not least in its implicit assumption that the death of Christ was not a sufficient atonement, but one which it was necessary to repeat daily. ${ }^{57}$ The precedent enshrined in Levitical law that required priests to retain their ritual purity in order that they might offer sacrifices presented no justification for the existence of a celibate, sacrificing New Testament priesthood; with no material sacrifice to offer, and the abrogation of the old law and ministry by the priesthood of Christ, there was no need for such ritual cleanness. The question was less the extent to which priestly incontinence profaned the sacred, and more whether the doctrine of transubstantiation itself was a pollutant, a doctrinal error which defiled the holy. ${ }^{58}$ A new relationship was posited between the morality of the priest and the actual theology of the eucharist; the unchaste priest did not impair the efficacy of the sacrament, but rather indicated the extent to which the very definition of the sacrament was flawed. Luke Shepherd used the name 'Philogamus', 'lover of women', to set the tone of Pathose, in which the base language and the supposed lascivious thoughts of the priest contributed to the mockery of both the mass and the celibate ideal. Idolatry and failed chastity were linked, with the allegation that unmarried priests were not only morally corrupt, but set up Priapus as their god. 59

56 John Ramsey, A Plaister for a galled horse (London, 1548), unpaginated.

57 Anon., The v. abhominable blasphemies conteined in the Masse (London, 1548), sigs A2r, A5r-B7v; Nicholas Pocock, 'The Condition of Morals and Religious Belief in the Reign of Edward VI', English Historical Review 10 (1895), 417-44, at 419-21.

58 Gilby, Deuillish Detection.

59 'Quod non estis Nupti / Eo plus Corrupti / Castum profitentes / Non custodientes / ... Incestui cedentes / Lupi Existentes / Priapo servientes / In Deum statuentes': Luke Shepherd, Pathose, or an Inward Passion of the Pope (London, c.1548), sigs B1r-v; see 
The character of 'Mistress Missa' featured prominently in evangelical polemic; a personification of the mass, frequently as a debauched woman, who condemned herself by her words and actions, and those of the unchaste priest in whose hands she was held. The feigned chastity of the priests supported the very deception contained within the mass itself, instituted 'vnder shadow and colour of holynesse, the more easely to seduce $\&$ deceyue the worlde'. ${ }^{60}$ In Hugh Hilarie's work, the personification of the ass expressed indignation that she was denounced as 'a thefe and a God robber, An harlot and a spirituall whore'. In the same vein, William Turner suggested that the pope and the mass had then begotten several children, including 'missa de pro defunctis, missa pro pluuia, masse de nomine Jesu', ${ }^{61}$ and a multitude of others. The sins of which the clergy were accused avarice, idolatry and concupiscence - were present at the heart of Catholic eucharistic theology, as both the cause and the fruit of its theological error.

Predictably, evangelical polemicists were swift to exploit any putative connection between clerical misconduct and the theology of transubstantiation precisely because of the debates over the connection between the purity of the priesthood and sacramental efficacy. However, the use of the image of the mass as a debauched woman ensured that the mass emerged from the pages of polemical pamphlets as the root cause of the immorality of the clergy. It was the mass that encouraged, or even required that priests forswear marriage in favour of adultery and depravity. A pamphlet in 1528 depicted clergy lamenting the fall of the mass in Strasbourg, where it had been 'The chief vpholder of our liberte / whereby our whores a[n]d harlots euerychone / Were maytayned in ryche felicite. ${ }^{62}$ In Hugh Hilarie's tract, the mass openly admitted that although she had the power to make people marry, and 'gyue you housebands and wyues at my pleasure', she preferred her 'smered shauelynges' to remain unmarried. ${ }^{63}$ Rather than being dishonoured by unchaste clergy,

also John N. King, English Reformation Literature: The Tudor Origins of the Protestant Tradition (Princeton, NJ, 1982), 269-70.

60 Anthony Marcourt, A Declaration of the Masse (London, 1548) sigs A6v-7r.

61 William Turner, A Breife Recantacion of maystres Missa (London, 1548), sig. A3r.

62 William Roy, Rede me and be nott Wroth (London, 1528), sigs A7r-A8v.

${ }^{63}$ Hugh Hilarie, The Resurreccion of the Masse / with the wonderful vertus of the same (Wesel, 1554), sigs A3r-v, Marcourt, Declaration, sig. E7r, cf. G4r. 
the figure of the mass claimed that 'Nothyng defyleth me / but honest marryage', and took delight in the number of idle and immoral clergy that were raised 'to be makers of christes' ${ }^{64}$ Clerical immorality could be attributed directly to the Catholic theology of the eucharist, not only in the suggestion that it was the prohibition of clerical marriage which led priests to keep concubines, but also in the depiction of a personification of the mass that positively demanded that priests behave in this manner. From this point, it was argued that the mass should be abolished, not because the impurity of the priesthood impacted upon the efficacy of the sacrament, but because such a corrupt sacrament, as the root cause of clerical immorality, could not be a true vehicle of salvation.

It is possible to perceive here the legacy of that 'latent' Donatism that seemed to reside in the concerns of the faithful about the purity of the priesthood. But the persistence of those concerns is not in itself explicit evidence of the survival of Donatism into the era of the Reformation. However, it is clear that Donatism, and with it other early church heresies such as Montanism, Manichaeism and Pelagianism, still had a pivotal role to play in the polemical literature of the English Reformation, on both sides. That stalwart of the genre, Thomas More, in the second part of his doggedly determined and detailed Confutation of Tyndale, for example, appealed to the authority of the old Augustine to pass judgement on the evangelicals as new 'Donatystes ... such heretykes then in Affryke as these be now in Almayne'. ${ }^{65}$ Stephen Gardiner, bishop of Winchester, turned to the condemnation of the Donatists in the early church in his defence of the Roman Catholic theology of the eucharist:

... accordyng herevnto S. Augustine againste the Donatistes geueth for a rule, the sacramètes to be one in all, although they be not one that receiue $\&$ vse them. Sainct Augustine hath these formal wordes in Latyn. Corpus Domini, \& sanguis Domini nibilominus erat etiam illis, quibus dicebat Apostolus: qui manducat indigne iudicium sibi māducat \& bibit. Which wordes be thus much in English. It was neuertheles the body of our Lorde, \& the bloud of our Lorde also vnto them, to

${ }^{64}$ Hilarie, Resurreccion, sigs A3r, A8r.

65 Thomas More, The second parte of the co[n]futacion of Tyndals answere in whyche is also confuted the chyrche that Tyndale deuyseth. And the chyrche also that frere Barns deuyseth (London, 1533), 331. 
whom thappostel sayde, he that eateth vnworthely, eateth and drynketh iudgement to himselfe. ${ }^{66}$

Richard Smyth or Smith, Oxford's Regius Professor of Divinity, in his defence of traditional religion in the reign of Mary Tudor, compared evangelicals to Donatists, citing Augustine's condemnation of Donatist iconoclasm: 'here, $\&$ in many other places of alters, whiche our new brethren did cast down, as the heritikes called Donatistes did, which neuer christiā good man did'. ${ }^{67}$ Robert Caly's 1554 edition of Vincent's Way home to Christ invoked the example of the Donatist schism and the division of the church that it threatened to create, this time as a judgement on the spread of evangelicalism. 'In the tyme of Donate that heretike of whom suche as maintaine his heresies be called Donatistes, what time a great part of Affricke ... forgettinge their religion and profession, preferred the cursed and blasphemous temeritie of one vayne man, before the vnitie of the churche'. ${ }^{68}$ In a similar vein, John Churchson's Brefe Treatise asserted a connection between the divisions within the North African church caused by Donatus and the state of the English church in the 1550s.

The scysmatycall churches be but partyculer multytudes in partyculer places, as the donatystes in Affryke, the hussytes in beame, the Lutherans in some certeyne prouinces of Germany, and the Sacramentaryes of late heare in Englande, wherfore it is most certaine, that our late particuler church, was not the church of Chryst, whyche is catholike that is to saye, vnyuersal thoroughoute all the vnyuersall world, as ye may perceyue by the promyse of God. ${ }^{69}$

The invocation of the dangers of Donatism was not the preserve of Catholic polemicists alone. John Bale situated the Donatist heresy

66 Stephen Gardiner, An explicatiō and assertion of the true Catholique fayth, touchyng the moost blessed Sacrament of the aulter with confutacion of a booke written agaynst the same (Rouen, 1551), 78, 82.

67 Richard Smith, A bouclier of the catholike fayth of Christes church, conteynyng diuers matters now of late called into controuersy, by the newe gospellers (London, 1554), 26. He was Regius Professor 1536-48, 1554-6 and during 1559.

68 Robert Caly, The waie home to Christ and truth leadinge from Antichrist and errour, made and set furth in the Latine tongue, by that famous and great clearke Vincent, Frenche man borne, aboue .xi. hundred yeres paste, for the comforte of all true Christian men, against the most pernitious and detestable crafte of heretikes (London, 1554), unpaginated.

69 John Churchson, A brefe treatyse declaryng what and where the churche is, that it is knowen, and whereby it is tryed and known (London, 1556), unpaginated. 
firmly within the internal structure of his apocalyptic history of the age-old struggle between the true church and the false in the Image of Both Churches, listing the heresies unleashed at the opening of the third seal. 'Then arose heresies and scismes, sectes, and deuisions, and were spred the world ouer, lyke as $\mathrm{y}^{\mathrm{e}}$ histories mencioneth', Bale claimed, and 'the Donatistes helde it necessarie to bée rebaptised' ${ }^{70}$ 'The Papists agree also with the heretiques / named Donatistes', Bale argued in his Apology, citing the history of Donatism as evidence that the Roman Catholic Church had usurped the name of the apostles. The Catholic priesthood, he protested, adopted a lifestyle which was itself a form of Donatism, while at the same time using the language of Donatism to condemn the sacraments of married priests. ${ }^{71}$ John Ponet, in his response to Stephen Gardiner, declared that 'the Papists agree also with the heretiques / named Donatistes'. scourging and punishing their flesh, and opposing clerical marriage. ${ }^{72}$ Thomas Cranmer's Confutation of Unwritten Verities warned against the practice of withdrawal from communion and seeking the church in man's own righteousness, describing it as a Donatist heresy which had been condemned. ${ }^{73}$ Cranmer was also willing to use the example of the Donatists to draw comparisons with sixteenth-century radicalism and sacramentarianism; as Jesse Hoover's work has shown, significant connections were made between Donatists (or at least the Donatists as they were constructed by their opponents) and religious radicalism in post-Reformation Europe, including Anabaptism and English separatism. ${ }^{74}$ The Donatist epithet acquired multiple meanings in the debates of the Reformation, anchored in its doctrinal characteristics,

\footnotetext{
70 John Bale, The Image of both Churches, after the most wonderfull and heauenly Reuelation of sainct Iohn the Euangelist, contayning a very fruitfull exposition or Paraphrase vpon the same (London, 1548), 74; Richard Bauckham, Tudor Apocalypse: Sixteenth-Century Apocalypticism, Millenarianism, and the English Reformation (Sutton Courtenay, 1978), 58; Leslie Fairfield, John Bale, Mythmaker for the English Reformation (Eugene, OR, 2006), 171.

71 John Bale, The apology of Iohan Bale agaynste a ranke papyst anuswering both hym and hys doctours, that neyther their vowes nor yet their priesthode areof [sic] the Gospell, but of Antichrist (London, 1550), 108, 118, 127.

72 John Ponet, An apologie fully answeringe by Scriptures and aunceant Doctors / a blasphemose Book gatherid by D. Steph. Gardiner (Strasbourg, 1556), 20, 45, 108.

73 Thomas Cranmer, A Confutatiō of vnwritte verities / both bi the holye scriptures and moste auncient autors (Wesel, 1556), unpaginated.

${ }^{74}$ Hoover, 'They bee Full Donatists'.
} 
but exploiting the subversive and dangerous implications that the heresy had acquired in its long written history.

The vigour of such polemical language did not override the underlying pastoral problem. Any reformed church that preserved a sacramental theology could not ignore entirely the connection between sacrament and ministry, and could no more allow the existence of concerns about the impact of clerical morality on sacramental efficacy than could its Roman Catholic opponents. As a result, arguments about the institutionalization of theological corruption were difficult to divorce from the kind of vocabulary used in Donatist objections to what they deemed to be the traditor church. Visitation articles from the mid-sixteenth century provide tantalizing glimpses into a lay anxiety that the character of the clergy might affect the validity of their sacraments. The specific question of 'whether any sayeth that the wickedness of the minister taketh away the effect of Christ's sacraments' suggests the existence of an anxiety that such beliefs existed. ${ }^{75}$ As Hoover and Marshall have observed, such anxiety is likely to have been associated with broader concern about the presence of Anabaptism in the English church, rather than the existence of Donatism in sixteenth-century England. Nonetheless, the connection between the vocabulary used in Anabaptism, and in the condemnation of it, does provide some indication of the ways in which the history of the Donatist heresy was readily invoked in the context of such concerns about doctrinal diversity and separatism. Article 26 of the Thirty-Nine Articles certainly engages both with the language of the Donatist controversy and with the ongoing challenge presented by Anabaptism:

Although in the visible Church the evil be ever mingled with the good, and sometimes the evil have chief authority in the Ministration of the Word and Sacraments, yet forasmuch as they do not the same in their own name, but in Christ's, and do minister by his commission and authority, we may use their Ministry, both in hearing the Word of God, and in the receiving of the Sacraments. Neither is the effect of Christ's ordinance taken away by their wickedness, nor the grace of God's gifts diminished from such as by faith and rightly do receive the Sacraments ministered unto them; which be effectual, because of Christ's institution and promise, although they be ministered by evil men.

75 W. H. Frere, Visitation Articles and Injunctions of the Period of the Reformation, 2 vols (London, 1907), 2: 239. 
The perpetual intermingling of the evil with the good in the community of the visible church was core to Augustine's argument against the Donatists, and the assertion that the sacraments administered by imperfect clergy were still received and effectual for the laity is indicative of an engagement with a much longer debate, and its lexicon, in the history of the church. ${ }^{76}$

In practical terms, the Donatist controversy and schism were, by the sixteenth century, a chronologically far distant period of discord from which the institutional Roman Catholic church had long since recovered. The inspiration that underpinned Donatist criticism of, and separation from, the North African church was the product of a particular political, social and devotional context in the region, conditions that did not pertain in other parts of Christian Europe in the centuries that followed. By the time of the Gregorian reform movement in the twelfth century, and even more so by the sixteenth century, Donatism was present in the institutional church not in a physical sense, but as a memory, as a vocabulary and as a convenient shorthand for dissent that was moralizing in its tone. It is at that level that the most obvious and interesting connections between institution and inspiration existed. The Donatist vision of the church was rich with a language of purity and holiness, rigorism and a deeply rooted desire to avoid contact with all, priests and practice, that had been tainted or polluted by accommodation with sin. That language resonated with the reforming impulses of the Gregorian papacy, but its use was effective, and possible, only because its connections with early Donatism were tenuous, rather than embedded in a heretical community that was visible in the eleventh-century church.

The original Donatist controversy was shaped by the rhetorical and theological construction of the priest as saint or sinner, a process of shaping that continued in discussions of purity and priesthood in the centuries that followed. That fraught relationship between inspiration and institution came to the fore in debates over the imposition of clerical celibacy and the escalation of expectation of clerical continence in the eleventh and twelfth centuries, but also in the debates over clerical marriage in the sixteenth. Debates over priestly purity in the medieval

76 E. J. Bicknell, A Theological Introduction to the Thirty-Nine Articles of the Church of England, 3rd edn (London, 1955), 353; the same statement is made in Article 27 of the 42 Articles (1553). 
and early modern church were informed by the same assumptions about the priesthood as the physical embodiment of the holiness of the church that had characterized Donatist thought. But the early history of Donatism was, to a large extent, written by those who had argued it out of existence, and then further polemicized by those who encountered the written record, not the material heresy. If the history of Donatism works at all as an example of the collision of inspiration and institution in the history of Christian priesthood, it is precisely because so much of its origins and early meaning had been distorted or lost. But in some ways, that makes its history all the more illuminating. Humbert, Damian, Hildebrand, the Waldensians, the collectors and promulgators of eucharistic miracle stories, lay testators who requested the services of honest priests, Bale, Gilby and Ramsay were not Donatists, but were all too aware of the polemical potential - and pitfalls - in invoking the language and legacy that had inspired that heresy in order to transform the institutional church. 